\title{
Is There a Bridge Between Systemic Lupus Erythematosus and Thymomas?
}

\author{
Sistemik Lupus Eritematöz ve Timoma Arasında Bir Köprü Var mı? \\ Xie QIBING, ${ }^{1}$ Yin HENG, ${ }^{2}$ Tao YE, ${ }^{2}$ Chen XI, ${ }^{1}$ Yin GENG $^{1}$ \\ ${ }^{1}$ Department of Rheumatology and Immunology, West China Hospital, Sichuan University, Chengdu, China \\ ${ }^{2}$ Department of Nephrology, West China Hospital, Sichuan University, Chengdu, China
}

In this report, we describe a 21-year-old male patient who developed a type $\mathrm{C}$ thymoma (undifferentiated carcinoma) after five years of stabilized systemic lupus erythematosus (SLE) activity. The patient remained stable even after chemoradiotherapy for the thymoma, and at the one-year follow-up, treatment had no effect on the progression of the SLE. Previous data regarding the coexistence of SLE and thymomas suggested that interaction occurs between these two diseases through some implicit mechanisms. However, we believe that no interaction takes place between two diseases, based on our experience and related literature data.

Key words: Systemic lupus erythematosus; thymectomy; thymoma.

Systemic lupus erythematosus (SLE) is associated with several immune abnormalities involving both $\mathrm{T}$ and B lymphocytes. ${ }^{[1]} \mathrm{A}$ thymoma is the only tumor that has been proven to generate mature $\mathrm{T}$ cells from immature precursors. ${ }^{[2]}$ Many people have suspected that the association between thymomas and SLE is not incidental ${ }^{[3-7]}$ due to the primary immunological role of the thymus and the purported abnormal functioning of the T lymphocytes in SLE. However, in our patient, the thymoma developed after five years of stabilized SLE activity, and the treatment for the thymoma did not change the state of the SLE.
Bu makalede, sistemik lupus eritematöz (SLE) aktivitesi stabil olduktan beş yıl sonra tip C timoma (diferansiye olmamış karsinom) gelişen 21 yaşında erkek bir olgu sunulmaktadır. Hasta timoma için verilen kemoterapiden sonra bile stabil kaldı ve bir yıllık takip sürecinde uygulanan tedavi SLE progresyonunu etkilemedi. Sistemik lupus eritematöz ve timoma birlikteliğine ilişkin daha önceki veriler, kesin olarak anlaşılamayan bazı mekanizmalar ile bu iki hastalığın birbirleriyle etkileştiğini işaret etmektedir. Ancak deneyimimiz ve ilgili literature verilerine dayanarak, bu iki hastalık arasında herhangi bir etkileşim olmadığı kanısındayız.

Anahtar sözcükler: Sistemik lupus eritematöz; timektomi; timoma.

Therefore, in spite of what has been presupposed, we hypothesize that there is no interaction between these two diseases.

\section{CASE REPORT}

For the past five years, a 21-year-old male patient with a past history of SLE had been receiving treatment with prednisone and hydroxychloroquine (200 mg bid) therapy at the rheumatology department of West China Hospital. The first onset of symptoms included oral ulcers, multiple serositis, multiple inflammatory synovitis, urine protein levels

Received: June 03, 2013 Accepted: July 04, 2013

Correspondence: Xie Qibing, M.D. Department of Rheumatology and Immunology, West China Hospital, Sichuan University, 610041 Chengdu, China. Tel: 86-18980601299 e-mail: xieqibing1971@163.com 
of $1.1 \mathrm{~g} / 24$ hours, positive anti-nuclear antibodies (ANA: 1:3200; speckled), and anti-double stranded DNA (anti-dsDNA) above the laboratory reference range (1:320), all of which fulfilled the criteria for SLE.

The patient was admitted to the rheumatology department at our West China Hospital in June of 2012 due to a two-month history of left chest pain accompanied by fatigue, accidental palpitation, and dyspnea. His lupus status was inactive at that time with a Systemic Lupus Erythematosus Disease Activity Index 2000 (SLEDAI-2K) score of 4 due to pleurisy and pericarditis. After thoracic computed tomography (CT), the existence of a tumor measuring $7.5 \mathrm{x} 11.5 \mathrm{~cm}$ was confirmed in the anterior mediastinum (Figure 1). A percutaneous biopsy also suggested a type $\mathrm{C}$ thymoma (undifferentiated carcinoma) (Figure 2) ${ }^{[8]}$ As a preoperative therapy, the patient had undergone four rounds of chemotherapy and 11 rounds of radiotherapy. At the one-year followup, his SLE was stable with a SLEDAI-2K score of 0.

\section{DISCUSSION}

In the past, some in vitro and in vivo experiments suggested that thymic abnormalities could play in role in the appearance of autoimmune diseases. ${ }^{[6,7]}$ In addition, some research declared that intratumor thymopoiesis could generate impaired $\mathrm{T}$ cells or alter the $\mathrm{T}$ cell repertoire and create a greater potential for the onset of autoimmune diseases such as SLE. ${ }^{[2,3]}$ In fact, it has been accepted as truth that thymomas can affect autoimmune diseases like SLE through some unknown mechanisms. ${ }^{[3-7]}$ If we follow this path of thought, it is also easy to deduce that for patients with both autoimmune diseases and thymomas, the

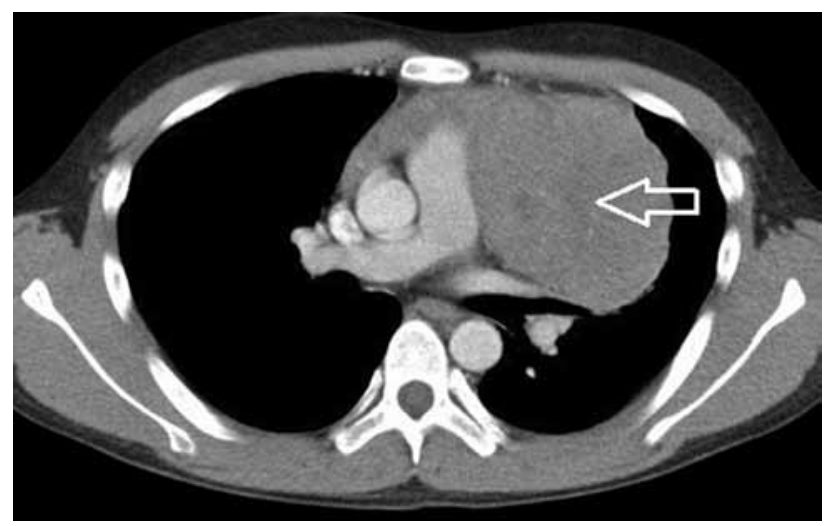

Figure 1. Thoracic contrast-enhanced computed tomography showing a mass of soft tissue density in the anterior mediastinum (white arrow). treatment given for thymomas, (i.e., a thymectomy) would improve the clinical outcomes of autoimmune diseases since there is a relationship between the two. Furthermore if there are some immunoregulations associated with both SLE and thymomas, then these two diseases are most likely to occur or, if already present, accelerate under dramatic changes such as when a thymectomy is performed or when the SLE is in the active stage. However, none of these hypothetical manifestations were observed in our patient. Meanwhile, a recent meta-analysis of thymomaassociated SLE suggested that variable outcomes are seen with this disease after thyroidectomies rather that the previously assumed improvement. ${ }^{[9]}$ Hence, we began to doubt the accepted assumptions regarding the connection between immunoregulations and thymomas and SLE. ${ }^{[3-7]}$

Additionally, we reviewed 24 cases in the literature published in English along with our own case, all of which had relatively detailed information about the patients' clinical features (Table 1), ${ }^{[4,5,10-24]}$ and discovered that most of the patients underwent surgery as the primary treatment for the thymoma, with some combining the surgery with radiotherapy and/or chemotherapy. The outcome of SLE varied after the treatment with remission in five of the 24 patients, exacerbation in seven others, no reported changes in five more, and SLE occurrence in the other six. We also noticed that there were no specific features in these patients with the different outcomes.

Therefore, we argue that the so-called interaction between thymomas and SLE does not exist. If this was the case, then the SLE would have accelerated after

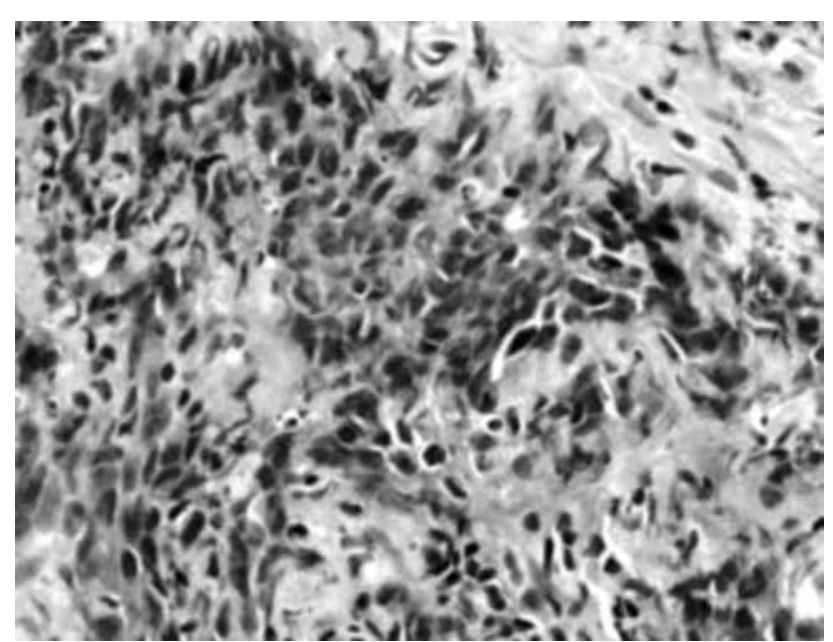

Figure 2. Undifferentiatied cell type seen in the thymoma (H-E x 40). 


\begin{tabular}{|c|c|c|c|c|c|}
\hline Author & $\begin{array}{l}\text { Gender/age } \\
\text { at diagnosis } \\
\text { of SLE }\end{array}$ & $\begin{array}{c}\text { Age at } \\
\text { discovery } \\
\text { of the thymoma }\end{array}$ & $\begin{array}{c}\text { Other autoimmune } \\
\text { disease }\end{array}$ & $\begin{array}{l}\text { Treatment for } \\
\text { the thymoma }\end{array}$ & SLE outcome \\
\hline Mastaglia, et al..$^{[10]}$ & $\mathrm{F} / 53$ & 55 & No & Surgery & Remission \\
\hline Mala et al. ${ }^{[1]}$ & $F / 36$ & 36 & No & Radiotherapy & No change \\
\hline Mizon et al. ${ }^{[12]}$ & $\mathrm{F} / 49$ & 49 & MG & $\begin{array}{l}\text { Surgery an } \\
\text { radiotherapy }\end{array}$ & Occurrence \\
\hline Calabrese et al. ${ }^{[13]}$ & $\mathrm{M} / 18$ & 21 & No & Surgery & Occurrence \\
\hline \multirow[t]{3}{*}{ Claudy et al. ${ }^{[14]}$} & $\mathrm{F} / 65$ & 67 & No & Surgery & No change \\
\hline & $\mathrm{F} / 68$ & 68 & No & - & Decreased \\
\hline & $\mathrm{F} / 55$ & 57 & No & Surgery & Exacerbation \\
\hline \multirow[t]{2}{*}{ Steven et al. ${ }^{[5]}$} & $\mathrm{F} / 49$ & 50 & No & $\begin{array}{l}\text { Surgery and } \\
\text { radiotherapy }\end{array}$ & Exacerbation \\
\hline & $\mathrm{F} / 48$ & 50 & No & $\begin{array}{l}\text { Surgery and } \\
\text { radiotherapy }\end{array}$ & Exacerbation \\
\hline Simeone et al. ${ }^{[15]}$ & Not reported & $\begin{array}{c}\text { One year } \\
\text { after diagnosis } \\
\text { of SLE }\end{array}$ & No & $\begin{array}{l}\text { Surgery and } \\
\text { radiotherapy }\end{array}$ & Remission \\
\hline Cruz et al..$^{[16]}$ & $\mathrm{F} / 57$ & 57 & $\begin{array}{l}\text { MG, pemphigus } \\
\text { erythematosus }\end{array}$ & Not reported & No change \\
\hline Fournel et al..$^{[17]}$ & $\mathrm{F} / 57$ & 57 & No & Chemotherapy & No change \\
\hline Ogawa et al. ${ }^{[18]}$ & $\mathrm{F} / 50$ & 49 & No & Surgery & Exacerbation \\
\hline Menon et al. ${ }^{[19]}$ & $\mathrm{F} / 62$ & 62 & No & Surgery & Remission \\
\hline Rosman et al..$^{[20]}$ & $\mathrm{F} / 42$ & 38 & No & Chemoradiotherapy & Occurrence \\
\hline \multirow[t]{2}{*}{ Zandman et al. ${ }^{[21]}$} & $\mathrm{F} / 30$ & 30 & No & Surgery & Remission \\
\hline & $\mathrm{F} / 48$ & 48 & No & Surgery & Exacerbation \\
\hline \multirow[t]{3}{*}{ Mevorach et al. ${ }^{[22]}$} & $\mathrm{F} / 66$ & 66 & No & Surgery & Occurrence \\
\hline & $\mathrm{F} / 66$ & 61 & No & Surgery & Occurrence \\
\hline & $\mathrm{F} / 26$ & 24 & MG & Surgery & Occurrence \\
\hline Duchman et al. ${ }^{[23]}$ & $\mathrm{F} / 53$ & 63 & $\begin{array}{l}\text { Pure red } \\
\text { cell aplasia }\end{array}$ & $\begin{array}{l}\text { Surgery and } \\
\text { radiotherapy }\end{array}$ & Remission \\
\hline Boonen et al. ${ }^{[4]}$ & $\mathrm{F} / 76$ & 76 & No & Surgery & Exacerbation \\
\hline Bozzolo et al. ${ }^{[24]}$ & $F / 27$ & 27 & No & Surgery & Exacerbation \\
\hline Our patient & $\mathrm{M} / 16$ & 21 & No & Chemoradiotherapy & No change \\
\hline
\end{tabular}

the onset of the thymoma or been alleviated after treatment for this tumor. At the very least, the outcome of SLE after a thymectomy ought to be unanimous, but none of these scenarios occurred in our patient or in the cases that we reviewed in the literature.

Finally, though we doubt that the relationship between SLE and thymomas is as close as was previously presumed, further studies with more evidence are needed to prove our hypothesis. However, our findings indicate that clinicians should not overlook the variable prognosis of SLE after treatment for thymomas.

\section{Declaration of conflicting interests}

The authors declared no conflicts of interest with respect to the authorship and/or publication of this article.

\section{Funding}

This work was supported by the National Natural Science Foundation of China (No.81172869 and No.30901339, to Qibing Xie) which did not influence the authors' judgement.

\section{REFERENCES}

1. Hahn BH. An overview of the pathogenesis of systemic lupus erythematosus. In: Wallace DJ, Hahn $\mathrm{BH}$, editor. Dubois' lupus erythematosus. 4th ed. Philadelphia: Lea \& Febiger; 1993. p. 67-70.

2. Hoffacker V, Schultz A, Tiesinga JJ, Gold R, Schalke B, Nix $\mathrm{W}$, et al. Thymomas alter the T-cell subset composition in the blood: a potential mechanism for thymoma-associated autoimmune disease. Blood 2000;96:3872-9.

3. Shelly S, Agmon-Levin N, Altman A, Shoenfeld Y. Thymoma and autoimmunity. Cell Mol Immunol 2011;8:199-202. 
4. Boonen A, Rennenberg R, van der Linden S. Thymomaassociated systemic lupus erythematosus, exacerbating after thymectomy. A case report and review of the literature. Rheumatology (Oxford) 2000;39:1044-6.

5. Steven MM, Westedt ML, Eulderink F, Hazevoet HM, Dijkman JH, Cats A. Systemic lupus erythematosus and invasive thymoma: report of two cases. Ann Rheum Dis 1984;43:825-8.

6. Horowitz S, Borcherding W, Moorthy AV, Chesney R, Schulte-Wisserman H, Hong R. Science. Induction of suppressor $\mathrm{T}$ cells in systemic lupus erythematosus by thymosin and cultured thymic epithelium. Science 1977;197:999-1001.

7. Steinberg AD, Law LD, Talal N. The role of NZB-NZW F1 thymus in experimental tolerance and auto-immunity. Arthritis Rheum 1970;13:369-77.

8. Rosai J, Sobin LH. Histological typing of tumours of the thymus. Berlin: Springer Verlag; 1999.

9. Zhang L, Dong J, Leng XM, Zeng XF. A meta-analysis of thymoma-associated systemic lupus erythematosus from 1975 - 2008 worldwide. Zhonghua Nei Ke Za Zhi 2009;48:643-6.

10. Mastaglia FL, Papadimitriou JM, Dawkins RL, Beveridge B. Vacuolar myopathy associated with chloroquine, lupus erythematosus and thymoma. Report of a case with unusual mitochondrial changes and lipid accumulation in muscle. J Neurol Sci 1977;34:315-28.

11. Malas D, Weiss S. Progressive multifocal leukoencephalopathy and cryptococcal meningitis with systemic lupus erythematosus and thymoma. Ann Neurol 1977;1:188-91.

12. Mizon JP, Morcamp D, Lefebvre P, Froissart M, Guidicelli $\mathrm{CP}$, Goasguen J. Associated myasthenia and disseminated lupus erythematosus. A report on two cases and complete review of the published literature (author's transl). Ann Med Interne (Paris) 1979;130:489-500. [Abstract]

13. Calabrese LH, Bach JF, Currie T, Vidt D, Clough J, Krakauer RS. Development of systemic lupus erythematosus after thymectomy for myasthenia gravis. Studies of suppressor cell function. Arch Intern Med 1981;141:253-5.
14. Claudy AL, Touraine JL, Schmitt D, Viac J, Moreau X. Thymoma and lupus erythematosus. Report of 3 cases. Thymus 1983;5:209-22.

15. Simeone JF, McCloud T, Putman CE, Marsh J. Thymoma and systemic lupus erythematosus. Thorax 1975;30:697700.

16. Cruz PD Jr, Coldiron BM, Sontheimer RD. Concurrent features of cutaneous lupus erythematosus and pemphigus erythematosus following myasthenia gravis and thymoma. J Am Acad Dermatol 1987;16:472-80.

17. Fournel P, Emonot A, Claudy AL, Boucheron S, Baril A. Thymoma and lupus: apropos of a case with recurrences and histological dedifferentiation. Rev Pneumol Clin 1987;43:98-101. [Abstract]

18. Ogawa M, Ueda S, Ohto M, Baba M, Yamaguchi Y, Kondo $\mathrm{Y}$, et al. Development of systemic lupus erythematosus after total resection of a thymoma and the adjacent thymic gland. J Rheumatol 1992;19:1130-2.

19. Menon S, Snaith ML, Isenberg DA. The association of malignancy with SLE: an analysis of 150 patients under long-term review. Lupus 1993;2:177-81.

20. Rosman A, Atsumi T, Khamashta MA, Ames PR, Hughes GR. Development of systemic lupus erythematosus after chemotherapy and radiotherapy for malignant thymoma. Br J Rheumatol 1995;34:1175-6.

21. Zandman-Goddard G, Lorber M, Shoenfeld Y. Systemic lupus erythematosus and thymoma--a double-edged sword. Int Arch Allergy Immunol 1995;108:99-102.

22. Mevorach D, Perrot S, Buchanan NM, Khamashta M, Laoussadi S, Hughes GR, et al. Appearance of systemic lupus erythematosus after thymectomy: four case reports and review of the literature. Lupus 1995;4:33-7.

23. Duchmann R, Schwarting A, Poralla T, Meyer zum Büschenfelde KH, Hermann E. Thymoma and pure red cell aplasia in a patient with systemic lupus erythematosus. Scand J Rheumatol 1995;24:251-4.

24. Bozzolo E, Bellone M, Quaroni N, Voci C, Sabbadini MG. Thymoma associated with systemic lupus erythematosus and immunologic abnormalities. Lupus 2000;9:151-4. 